\title{
ABSTRACTS AND NOTES ON CONTRIBUTORS
}

DAVID A. JONES

University of Warsaw, Institute of The Americas and Europe, American Studies Center and Faculty of Management

\section{America's Automobile: Affection or Obsession, Myth or Reality?}

Mythology plays an important part of the role of the American automobile, less so in terms of its primary function that is transportation, more so in terms of an ancillary purpose: its metaphorical significance to both owner or operator and the onlooking public. Across much of the 20th century and continuing now into the third decade of the 21st century, the American automobile has undergone many design changes that have buttressed its metaphorical significance: become streamlined, gained then lost then partially regained size together with a colorful exterior, and in the 21st century become focused on an array of interior gadgets, some cast into hibernation because of an electronic chip scarcity resulting from trade wars and the Covid-19 pandemic. Many Americans seem to have almost become besotted by automobiles, including their own and those driven by others, because in some respects the American automobile has come to define its driver. Automobiles in the United States that are visually appealing symbolize affluence, material success, preoccupation with speed, including the rapid pace of social change, as well as, at least arguably, a lesser regard for protecting the environment. On balance, in the mindset of many Americans, the automobile is larger than life, "a mode of signification, a form" in contrast to a mere machine. Change in automotive design has been heralded as the talisman of a new generation of drivers. However, what is cause and what is effect? American automobiles conflate myth and reality; that which is together with that which might be sometime temporal frustrations with the American Dream.

Keywords: American Dream, automobile, mechanical Manifest Destiny, mobility, muscle cars, wartime Nazi collaboration

David A. Jones is University of Warsaw Professor dr hab. (Political Science) of International Relations and International Management. He has
Carculture(s)

Machines, Roads

Mythologies

RIAS vol. 14,

Fall-Winter,

№ 2/2021 
been at its Institute of The Americas and Europe, American Studies Center, since 2005, Faculty of Management since 2012, and Institute of International Relations from 2006 to 2016. He is a senior graduate faculty at Norwich University, the Military Academy of the State of Vermont, where he teaches Intercultural Management in the International System and has taught its capstone graduate course, Global Corporate Diplomacy, receiving its Distinguished Faculty Award in 2018. Professor Jones received the University of Warsaw Rector's Award in 2017 for his book, Four Eagles and a Dragon: Successes and Failures of Quixotic Encirclement Strategies in Foreign Policy: An Analysis (Bloomsbury 2016). From 2000-2005 he was faculty advisor to the Oxford Banking Forum at Oxford University. He is a Fellow of the Royal Society of Medicine (FRSM) and Royal Statistical Society (FRSS), and holder of patents including a U.S.P.T.O. utility patent, several design patents registered in the United States, Canada, European Community, and Republic of China (Taiwan).

\section{ELTON G. MCGOUN}

William H. Dunkak Emeritus Professor of Finance

Freeman College of Management, Bucknell University

\section{Crazy ‘Bout a Mercury}

When we purchase an automobile, we are also acquiring an amorphous but very real image, that is, the statement which the automobile makes about its owner to the public. Such images are forged in popular culture, and Mercury is an automobile brand that had an auspicious post-WWII popular culture debut. In 1948, K.C. Douglas recorded "Mercury Boogie" on a 10-inch 78-RPM, with its memorable line in the chorus "I'm crazy 'bout a Mercury." Five years later in 1953, George and Sam Barris transformed a 1951 Mercury Club Coupe into the Hirohata Merc, creating a classic of customization that has been described as "the most famous custom of all time"

CarCulture(s) Machines, Roads Mythologies (Taylor 2006: 56). Ford occasionally attempted to take advantage of these strong roots in popular culture formed in the make's earliest days, but the company's efforts were not notably successful. In spite of Mercury's promising beginnings in media, it has had only a slight presence in music and film. Mercury's image never influenced the automobile market beyond the first few years, and it was unable to prevent the brand's 2011 demise.

Keywords: automobile, popular music, blues, brand image, popular culture

Before becoming a scholar of international business and finance and eventually automotive history, Skip McGoun earned his bachelor's degree in biology at the Illinois Institute of Technology, served as a supply officer in the US Navy, and worked in Alaska for a credit union. After earning his MBA at the University of Alaska-Anchorage and doctorate at Indiana University, he settled in at Bucknell University 34 years ago. His collaborations have led to summer teaching positions at the Uni- 
versity of Ljubljana, Slovenia and the University of Donja Gorica, Montenegro, and he has made presentations at a number of other universities and international conferences. He also served as the Area Chair of Vehicle Culture for the Popular Culture Association.

\section{EWA WYLĘŻEK-TARGOSZ}

University of Silesia in Katowice, Poland

\section{Car Painting in America: Edward Hopper's Visions of the Road}

The article presents an analysis of three paintings by one of the greatest American realist painters, Edward Hopper. The three selected works share a common denominator: they all address the concept of a car and the influence it has on the nation's life-it has altered the way people traveled and expressed their identity. A car in Hopper's works serves a twofold function, it allows its drivers and passengers to experience the land more as they can travel wherever they desire but, on the other hand, it contributes to a separation from their environment as the journey involves fragmentariness and rootlessness.

Keywords: Edward Hopper, modernism, painting, American studies

Ewa Wylężek-Targosz, PhD, is a lecturer at the Institute of Literary Studies in the Faculty of Humanities of the University of Silesia, Katowice, Poland. Her main academic interests are carnival, modernism, art history, and cinema studies. In 2019 she was a guest lecturer at University of Eastern Finland. Currently, she teaches Introduction to American Film, North American Art History and Creative Writing, as well as Writing for the Media. She has recently published a book titled Tropes of Tauromachy: Representations of Bullfighting in Selected Texts of Anglophone Literature (University of Silesia Press). She is also a certified brewer (postgraduate course at University of Agriculture, Kraków, Poland).

\section{JOHN ERIC STARNES}

\section{University of Silesia in Katowice, Poland}

\section{The Rebel Behind the Wheel: An Examination of the 'Redneck' Rebel Cultural Trope in The Dukes of Hazzard}

The heyday of 'Redneck' cinema-the 1970s to early 1980s, saw the rise of the Redneck Rebel-a Southern or otherwise 'hick' antihero who rode around the countryside like a modern-day cowboy vanquishing evil. His 'horse' was his car-a beefed up/souped up muscle car that often became the star of the show and overshadowed the anti-hero himself. This article examines the Redneck Rebel through the lens of one American TV series-The Dukes of Hazzard. This popular 1980s TV series, along with its antecedents and contemporaries, underscore several important points that reinforce typical conservative American virtues: freedom, fighting the 'good fight,' an overt heterosexuality, a particular reveling in a sarcastic 'sticking out the tongue' at the overly sophisticated, 
overly arrogant, 'anti-American,' and well-heeled parts of American society.

Keywords: The Dukes of Hazzard, cars, television series, redneck culture

Eric Starnes, PhD, is a native of Catawba county, North Carolina. He holds a BA (1990) and an MA (1995) in Russian/East European History from Appalachian State University and a PhD (2018) in American Literature from the University of Silesia in Katowice, Poland. He has published several articles on American white nationalist fiction, the men's movement and men's adventure fiction. His current research interests include American white nationalist fiction, Nazi occultism in American pulp fiction, and conspiracy theories in American pulp fiction.

\section{SASHA GORA}

Center for the Humanities o Social Change,

Ca' Foscari University of Venice, Italy

\section{Buddies, Lovers, and Detours: America and its Road Movies}

Is an open road also a democratic one? Zooming in on two filmsQueen o Slim (2019) and Unpregnant (2020)-this article discusses American road movie genre from the perspective of 2021, and how contemporary film narratives intersect with race and gender One movie often drives in another film's lane, meaning the genre is self-referential. Unfolding in three parts, the article begins by introducing these two films and surveying how they contribute to the road movie genre. It then discusses cars and clothing as characters and concludes by considering surveillance and how these films, in tandem, take the temperature of contemporary American society.

CarCulture(s) Machines, Roads Mythologies

Keywords: film, road movie, mobility, police brutality

A cultural historian and writer, L. Sasha Gora graduated in 2020 with a PhD (summa cum laude) in American Studies from Ludwig Maximilian University of Munich. She is currently a postdoctoral fellow at the Center for the Humanities and Social Change at Ca' Foscari University of Venice, and is working on her first book titled Culinary Claims: A History of Indigenous Restaurants in Canada.

JAMES J. WARD

Cedar Crest College, USA

\section{Existential Definition at the End of the American Road: Zabriskie Point (1970), Vanishing Point (1971), The Gauntlet (1977)}

This article discusses three films that helped landmark American cinema in the 1970 s. Although differing in inception and recep- 
tion, all three belong loosely to the genre of the road movie and are linked by protagonists whose stances of rebellion and alienation were characteristic of the counterculture of the $1970 \mathrm{~s}$ and by the broader theme of existential self-definition that still influences moviemaking today. A critical and commercial failure on its release in 1970, Michelangelo Antonioni's Zabriskie Point has been revalorized as an ambitious attempt to represent the political and cultural conflicts that seemed to be fracturing American society at the time. In contrast, Richard Sarafian's Vanishing Point soon overcame the disadvantage of studio disinterest and established itself as a cult favorite. Arguably the definitive anti-hero of 1970 s cinema, the amphetamine-fueled renegade driver played by Barry Newman achieves iconic stature through an act of defiant self-destruction that still leaves viewers of the film stunned. Finally, Clint Eastwood's The Gauntlet, in which the actor-director breaks with his 'Dirty Harry' persona to depict a burned-out cop who redeems a ruined career, and enables himself a new start, not by making his own law but by enforcing the law on the books, and against all odds. In all three films, the still unspoiled landscape of the American Southwest, crisscrossed by its skein of highways, provides the tableau for escapist fantasies that may in fact be real, for high-speed chases and automotive acrobatics that defy the laws of physics, and for vignettes of an 'outsider' way of life that was already beginning to perish.

Keywords: road movie, existentialism, anti-hero, 1970 s cinema, Zabriskie Point, Vanishing Point, The Gauntlet

James J. Ward is professor emeritus of history at Cedar Crest College in Allentown, Pennsylvania where he taught courses in German history, Russian history, urban history, and film and history. He has published articles and reviews in The Journal of Contemporary History, The Journal of Interdisciplinary History, Central European History, Slavic Review, The Journal of Popular Culture, The Historical Journal of Film, Radio, and Television, The Quarterly Review of Film and Video, and Film o History, among others. He has also contributed chapters to numerous scholarly anthologies in film studies. With Cynthia J. Miller, he co-edited Urban Noir: New York and Los Angeles in Shadow and Light (Rowman \& Littlefield, 2017).

\section{TOMASZ BURZYŃSKI}

University of Silesia in Katowice, Poland

\section{Pandemic Automobility: Patterns of Crisis and Opportunity in the American Motor Culture}

This article traces the recursive character of automobility from a perspective of cultural crises and traumas that accompany motor culture development in the USA. The American automobility system has been caught in the treadmill of ideological criticism that defined the current role of motor vehicles in forms of political activism and cultural 
criticism. The ongoing Covid-19 pandemic is different as it seems to bring restoration to the original character of motor culture with its defining features of individualism, freedom, and opportunity achieved through mobility.

Keywords: automobility, Covid-19, medicalization, trauma, risk

Tomasz Burzyński received his PhD in 2009 from the University of Silesia in Katowice, Poland. He works at the Institute of Literary Studies where he teaches sociology, media studies, and cultural studies. His research interests include cultural studies and cultural theory, sociology of risk, theories of trust, and discourses of health and illness. Recent publications include "Sociologizing Automotive Heritage. Traditions of Automobile Folklore and the Challenges of Risk Society," in The Routledge Companion to Automobile Heritage, Culture, and Preservation (J. Clark, B. Stiefel, eds., Routledge 2020) and "Systemic Intertextuality: A Morphogenetic Perspective," Text Matters: A Journal of Literature Theory and Culture 10 (2020).

\section{MARCIN MAZUREK}

University of Silesia in Katowice, Poland

Marcin Mazurek, PhD, Guest-Editor of the present volume, is an Assistant Professor at the Institute of Literary Studies of the Faculty of Humanities at the University of Silesia in Katowice, Poland. His research interests are in postmodern theory, culture-technology relationships, consumerist criticism, visual culture and automobility studies. He is the author of a number of articles in the abovementioned fields, co-editor of Camouflage. Discourses of Deception, Transparency and Exposure (2010) and Camouflage. Secrecy and Exposure in Cultural and Literary Studies (2014), and the author of A Sense of Apocalypse. Technology, Textuality, Identity (2014). He is

CarCulture(s) Machines, Roads Mythologies also the Academic Secretary of Er(r)go. Theory-Literature-Culture, an international scholarly journal published by the University of Silesia Press. In 2016, under the auspices of Interdisciplinary.Net, he organized and chaired an international conference titled Cars in/of Culture: Mobility, Materiality, Representation held in Oxford, UK.

\section{JUSTIN MICHAEL BATTIN}

RMIT University in Ho Chi Minh City, Vietnam

Justin Michael Battin, PhD, Associate Editor of RIAS, is Senior Lecturer at RMIT University in Ho Chi Minh City. His research focuses on intersecting various strands of Martin Heidegger's philosophy with the everyday uses of mobile media technologies and mobile social media. His interests revolve around such areas as mobile, social, and digital media, phenomenology and place-making practices, critical and cultural theory, and philosophy of technology. His publications include: Reading Black Mirror: Insights into Technol- 
ogy and the Post-Media Condition (co-edited with German A. Duarte, 2021), We Need to Talk About Heidegger: Essays Situating Martin Heidegger in Contemporary Media Studies (co-edited with German A. Duarte, 2018), Mobile Media Technologies and Poiésis: Rediscovering How We Use Technology to Cultivate Meaning in a Nihilistic World (2017). In 2021 he has received the RMIT Vietnam Excellence in Learning and Teaching Award for Outstanding Contributions to Student Learning.

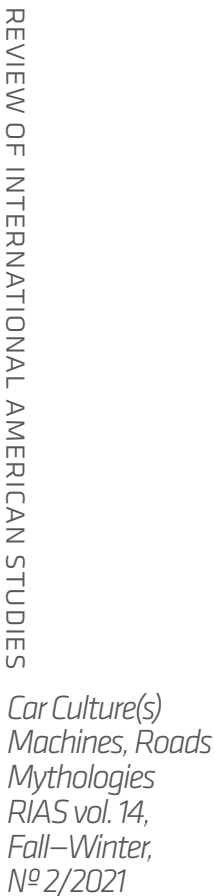


